\title{
Cell specific apoptosis by RLX is mediated by NFkB in human colon carcinoma HCT-116 cells
}

\author{
Asif Khurshid Qazi', Aashiq Hussain ${ }^{1}$, Mushtaq A Aga², Shakir Ali, Subhash Chandra Taneja², Parduman Raj Sharma', \\ Ajit Kumar Saxena ${ }^{1}$, Dilip M Mondhe ${ }^{1}$ and Abid Hamid ${ }^{1 *}$
}

\begin{abstract}
Background: Resistance to chemotherapy represents a major obstacle in correcting colorectal carcinomas (CRC). Inspite of recent advances in the treatment of metastatic disease, the prognosis of the patients remains poor. RLX, a vasicinone analogue has been reported to possess potent bronchodilator, anti-asthmatic and anti-inflammatory properties. However, its anti-cancer activity is unknown.

Results: Here, we report for the first time that RLX has anti-cancer property against panel of human cancer cell lines and most potent activity was found against HCT-116 cells with $\mathrm{IC}_{50}$ value of $12 \mu \mathrm{M}$ and have further investigated the involvement of NFKB and caspase-3 in RLX action in CRC apoptosis. Following RLX and BEZ-235 treatment in HCT-116, we observed significant down-regulation of NFKB (1 to 0.1 fold) and up-regulation of caspase-3 (1 to 2 fold) protein expressions. Additionally, morphological studies revealed membrane blebbing, cell shrinkage, chromatin condensation and finally apoptosis in HCT-116 cells.
\end{abstract}

Conclusions: Overall, these findings indicate that RLX is a potent small molecule which triggers apoptosis, and promising potential candidate to be a chemotherapeutic agent.

Keywords: Colorectal cancer, Apoptosis, Chemotherapy, Proliferation, Migration

\section{Background}

According to Global cancer statistics, throughout world, cases of colorectal carcinoma (CRC) switched to 1.2 million with more than 600000 deaths per year [1]. In females, $\mathrm{CRC}$ is the second leading commonly diagnosed and third highly mortal cancer whereas in case of males, it is the third most commonly diagnosed and fourth most common cause of mortality. Promotion from normal colonic epithelial cells into a colorectal carcinoma is a multifactorial process. There are many factors like cell proliferation, inflammation, migration and angiogenesis which play an important role in CRC development and progression [2]. Conventional combination chemotherapy regimens involving FOLFOX (5-FU with leucovorin and oxaliplatin), FOLFORI (5-FU with leucovorin and irinotecan), IFL (Irinotecan, 5-FU, leucovorin) and XELOX (Capecitabine and oxaliplatin) for the treatment of colorectal

\footnotetext{
* Correspondence: ahdar@iiim.ac.in

'Cancer Pharmacology Division, CSIR-Indian Institute of Integrative Medicine, Jammu 180001, India

Full list of author information is available at the end of the article
}

cancer [3] have limited efficacy and are associated with significant toxicity.

Colorectal cancer represents a life-threatening complication of inflammatory bowel diseases where NFkB is a natural suspect in providing a mechanistic link between inflammation and carcinogenesis. Presently, it is believed that increasing knowledge on genetic control of cellular proliferation, migration and modulation of key proteins like NFkB that are aberrant in colorectal cancer have the potential to provide an effective and improved approach for its management [4]. The molecular mechanisms underlying this process have only recently started to be clarified with biochemical and genetic studies [5]. NFKB is a key inflammatory mediator involved in initiation, progression and metastasis of CRC [6]. A variety of carcinogens and tumor promoters have shown to activate $\mathrm{NF} \mathrm{KB}$. Constitutive expression of $\mathrm{NF}_{\mathrm{K} B}$ is frequently found in tumor cells and is constitutively activated in a number of human cancers via PI3K signaling [7]. Furthermore, NFkB activation is regulated by caspase- 3 which cleaves $I \kappa B \alpha$, generating a cleavage fragment that potentially acts as a constitutive inhibitor of $\mathrm{NFK}_{\mathrm{K}}$ [8]. 
On the contrary, down regulation of $\mathrm{NFKB}$ has been reported to be implicated in the HCT-116 apoptotic cell death [9]. In vitro treatment of HCT-116 cell lines with NVP-BEZ235, a dual pan-class I PI3K and mTOR kinase inhibitor in clinical trials has shown decrease in cell viability and ex-vivo analysis of tumors demonstrated a 56\% decreased proliferation in CRC [10].

Adhatoda vasica Nees (family Acanthaceae), commonly known as Vasaka or Arusha is a well known herb in indigenous system of medicine for its beneficial effects. Vasicinone obtained from leaves of Adhatoda vasica Nees has been reported for moderate degree of bronchodilator and anti-cancer activity. In previous study, it has been shown that RLX, a vasicinone analogue has varied medicinal properties $[11,12]$. Here, we report for the first time that RLX has potent anti-cancer property against colon cancer HCT-
116 cells. Under the tested experimental conditions, we established a differential anti-cancer effect of RLX in comparison with BEZ-235. The results demonstrated that RLX inhibits cell proliferation, decreases $\mathrm{NFK}_{\mathrm{K}} \mathrm{B}$ and increases caspase-3 expression, suppresses cell migration, causes cell membrane blebbing followed by nuclear condensation of colon cancer cell and culminate apoptosis in HCT-116 cells. These findings revealed the importance of RLX as an anti-cancer agent in treatment of colon carcinoma.

\section{Results}

In vitro screening of vasicinone analogues and BEZ-235 improves growth inhibitory effect in various human cancer cell Line

We evaluated inhibitory efficacy in-vitro MTT viability assay against panel of cancer cell lines and relative $\mathrm{IC}_{50}$

Table 1 Growth inhibitory effect of vasicinone analogues, BEZ-235 and 5-Flurouracil against panel of human cancer cell lines

\begin{tabular}{|c|c|c|c|c|c|c|c|c|c|c|}
\hline \multirow{2}{*}{\multicolumn{3}{|c|}{$\begin{array}{c}\text { Tissue type } \\
\text { Cell type }\end{array}$}} & \multirow{2}{*}{$\begin{array}{c}\text { Leukemia } \\
\text { THP-1 }\end{array}$} & \multirow{3}{*}{$\begin{array}{l}\text { Prostate } \\
\text { PC-3 }\end{array}$} & \multicolumn{2}{|c|}{ Breast } & \multirow{2}{*}{$\begin{array}{l}\text { Pancreas } \\
\text { MIAPaca } 2\end{array}$} & \multicolumn{2}{|c|}{ Colon } & \multirow{3}{*}{$\begin{array}{c}\text { Epithelial (Normal) } \\
\text { fR-2 }\end{array}$} \\
\hline & & & & & \multirow[t]{2}{*}{ T47D } & MCF-7 & & НCT-116 & Caco-2 & \\
\hline S. No & Structure & Conc $(\mu \mathrm{M})$ & \multicolumn{5}{|c|}{$\%$ Growth inhibition } & & & \\
\hline \multirow[t]{5}{*}{1} & & 50 & $53 \pm 2$ & $30 \pm 3$ & $66 \pm 2$ & $68 \pm 2$ & $53 \pm 3$ & $96 \pm 1$ & $30 \pm 3$ & $20 \pm 2$ \\
\hline & & 30 & $52 \pm 3$ & $29 \pm 2$ & $55 \pm 1$ & $54 \pm 1$ & $40 \pm 5$ & $82 \pm 1$ & $26 \pm 4$ & $14 \pm 1$ \\
\hline & & 20 & $44 \pm 4$ & $21 \pm 1$ & $42 \pm 0$ & $42 \pm 2$ & $31 \pm 4$ & $79 \pm 2$ & $20 \pm 5$ & $12 \pm 2$ \\
\hline & & 10 & $32 \pm 2$ & $12 \pm 4$ & $12 \pm 5$ & $32 \pm 1$ & $14 \pm 3$ & $37 \pm 2$ & $10 \pm 2$ & $8 \pm 1$ \\
\hline & & 5 & $4 \pm 1$ & $5 \pm 3$ & $6 \pm 2$ & $11 \pm 1$ & $5 \pm 2$ & $4 \pm 1$ & $5 \pm 1$ & $3 \pm 2$ \\
\hline \multirow[t]{5}{*}{2} & & 50 & $42 \pm 1$ & $30 \pm 2$ & $49 \pm 3$ & $33 \pm 3$ & $47 \pm 3$ & $43 \pm 3$ & $10 \pm 3$ & $10 \pm 2$ \\
\hline & & 30 & $40 \pm 2$ & $23 \pm 3$ & $42 \pm 2$ & $20 \pm 3$ & $41 \pm 2$ & $27 \pm 1$ & $3 \pm 2$ & $6 \pm 1$ \\
\hline & & 20 & $33 \pm 2$ & $11 \pm 2$ & $35 \pm 3$ & $11 \pm 3$ & $39 \pm 3$ & $20 \pm 1$ & $2 \pm 2$ & $4 \pm 2$ \\
\hline & & 10 & $20 \pm 1$ & $7 \pm 2$ & $30 \pm 3$ & $1 \pm 1$ & $18 \pm 2$ & $18 \pm 2$ & $1 \pm 3$ & $1 \pm 1$ \\
\hline & & 5 & $8 \pm 2$ & $1 \pm 3$ & $10 \pm 1$ & $1 \pm 1$ & $9 \pm 1$ & $11 \pm 3$ & $1 \pm 3$ & $1 \pm 2$ \\
\hline \multirow[t]{5}{*}{3} & & 50 & $45 \pm 1$ & $37 \pm 3$ & $30 \pm 3$ & $5 \pm 1$ & $44 \pm 3$ & $29 \pm 1$ & $10 \pm 3$ & $12 \pm 1$ \\
\hline & & 30 & $42 \pm 2$ & $29 \pm 1$ & $22 \pm 2$ & $2 \pm 1$ & $30 \pm 2$ & $29 \pm 3$ & $8 \pm 2$ & $10 \pm 1$ \\
\hline & & 20 & $6 \pm 2$ & $10 \pm 2$ & $21 \pm 1$ & $2 \pm 2$ & $15 \pm 1$ & $21 \pm 2$ & $3 \pm 3$ & $6 \pm 2$ \\
\hline & & 10 & $4 \pm 1$ & $9 \pm 1$ & $4 \pm 1$ & $1 \pm 1$ & $11 \pm 3$ & $21 \pm 2$ & $1 \pm 1$ & $2 \pm 1$ \\
\hline & & 5 & $3 \pm 3$ & $8 \pm 2$ & $1 \pm 3$ & $1 \pm 1$ & $10 \pm 2$ & $5 \pm 3$ & $1 \pm 2$ & $3 \pm 1$ \\
\hline \multirow[t]{5}{*}{4} & & 50 & $30 \pm 3$ & $40 \pm 1$ & $20 \pm 2$ & $49 \pm 2$ & $12 \pm 1$ & $30 \pm 2$ & $10 \pm 1$ & $20 \pm 1$ \\
\hline & & 30 & $22 \pm 1$ & $27 \pm 2$ & $10 \pm 1$ & $40 \pm 1$ & $10 \pm 2$ & $23 \pm 1$ & $10 \pm 2$ & $16 \pm 2$ \\
\hline & & 20 & $21 \pm 3$ & $20 \pm 1$ & $8 \pm 1$ & $19 \pm 3$ & $6 \pm 1$ & $11 \pm 3$ & $7 \pm 1$ & $14 \pm 1$ \\
\hline & & 10 & $4 \pm 1$ & $18 \pm 1$ & $7 \pm 1$ & $10 \pm 1$ & $2 \pm 1$ & $7 \pm 3$ & $5 \pm 1$ & $11 \pm 2$ \\
\hline & & 5 & $2 \pm 2$ & $11 \pm 3$ & $2 \pm 1$ & $4 \pm 2$ & $1 \pm 3$ & $1 \pm 3$ & $2 \pm 3$ & $10 \pm 1$ \\
\hline 5 & BEZ-235 & $10 \mathrm{nM}$ & - & - & $50 \pm 2$ & - & $53 \pm 4$ & $51 \pm 1$ & - & $26 \pm 1$ \\
\hline 6 & 5-Flurouracil & $20 \mu \mathrm{M}$ & - & - & - & - & - & $62 \pm 1$ & - & $70 \pm 2$ \\
\hline
\end{tabular}


for $48 \mathrm{~h}$. Initially, we screened vasicinone analogue at indicated concentrations $(5,10,20,30$ and $50 \mu \mathrm{M})$, BEZ$235(10 \mathrm{nM})$ and 5-Flurouracil $(20 \mu \mathrm{M})$ (Table 1) against Leukemia (THP-1), Prostate (PC-3), Breast (MCF-7, T47D), Pancreatic (MIAPaca 2), Colon (HCT-116, Caco-2) cancer cell lines and normal epithelial cells (fR-2) for $48 \mathrm{~h}$. Among molecules tested, RLX (Figure 1A) showed concentration dependent inhibitory effect on cell proliferation against THP-1, T47D, MIAPaca 2, MCF-7 and HCT-116 cancer cell lines and most potent inhibition against HCT-116 whereas no significant effect on cell viability was observed in cells treated with other analogues at same concentrations. The MTT assay result revealed that HCT-116 cells treated with RLX induced growth inhibition of the order of $96 \%, 82 \%$ and $79 \%$ at a concentration of 50, 30 and $20 \mu \mathrm{M}$ (Figure 1B). However, BEZ-235 (Positive control) at 10nM showed only $50 \%, 53 \%$ and $51 \%$ growth inhibition against T47D, MIAPaca-2 and HCT-116 whereas 5-FU (Positive control) a known anticancer agent against colon cancer, showed 56\% growth inhibition against HCT-116 with cytotoxicity against normal epithelial cells (fR-2). Furthermore, $\mathrm{IC}_{50}$ value of RLX was calculated against panel of cell lines which was found least against HCT116 cells $(12 \mu \mathrm{M})$ (Table 2$)$. Moreover, RLX showed growth inhibition of $23 \%, 14 \%, 12 \%, 8 \%$ and $3 \%$ at 50 , 30, 20, 10 and $5 \mu \mathrm{M}$ against fR-2 (Normal epithelial), indicated that it requires six to eight time's higher concentration of RLX to induce $50 \%$ cell death in normal epithelial (fR-2) cell line. Interestingly, these results

\section{A}

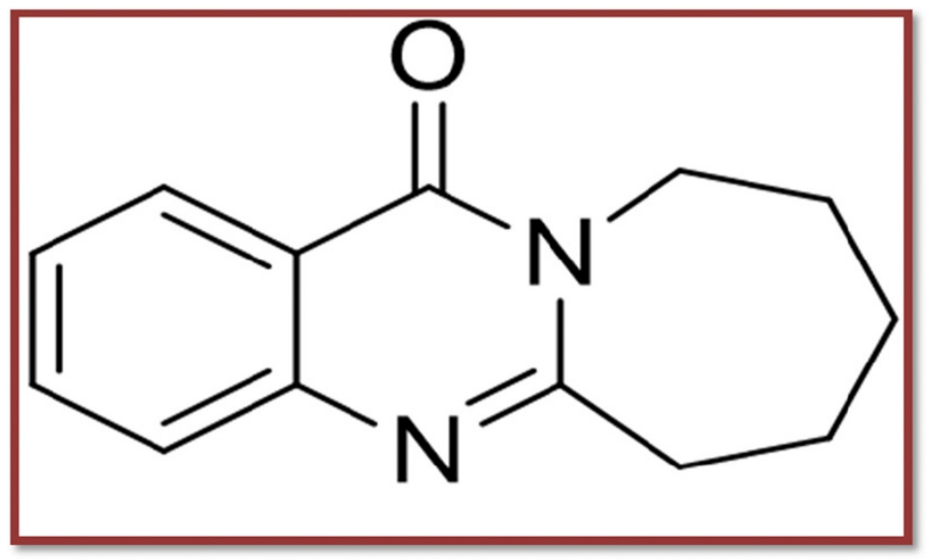

B

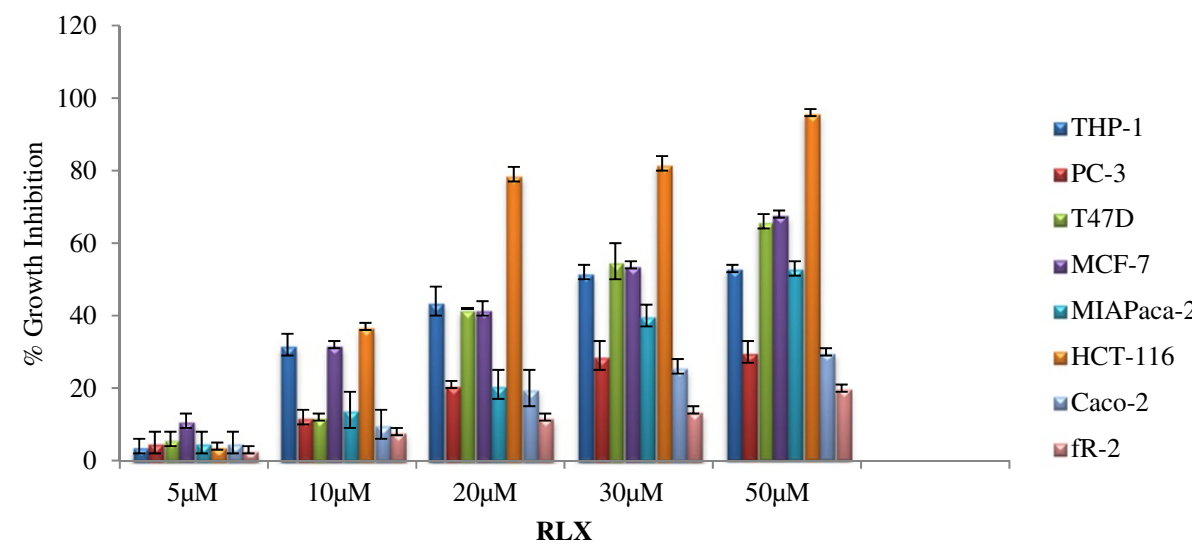

Figure 1 Effect of RLX on cell proliferation. (A) Chemical structure of RLX (7, 8, 9, 10-Tetrahydroazepino [2, 1-b] quinazolin-12(6H)-one). (B) Percentage growth inhibition of RLX $(5 \mu \mathrm{M}, 10 \mu \mathrm{M}, 20 \mu \mathrm{M}, 30 \mu \mathrm{M}$ and $50 \mu \mathrm{M})$ against panel of human cancer cell lines including normal epithelial cell line. As depicted in Figure, RLX showed concentration dependent growth inhibition and potent effect were shown at $20 \mu \mathrm{M}$, $30 \mu \mathrm{M}$ and $50 \mu \mathrm{M}$ against HCT-116 cells. 
Table 2 Calculated IC 50 values of RLX against human cancer cells and normal epithelial cells

\begin{tabular}{ccc}
\hline Tissue & Cell line & $\mathbf{I C}_{\mathbf{5 0}}(\boldsymbol{\mu} \mathbf{M})(\mathbf{R L X})$ \\
\hline Leukemia & THP-1 & 27 \\
Prostate & PC-3 & $>50$ \\
Breast & T47D & 24 \\
Breast & MCF-7 & 28 \\
Pancreas & MIAPaca 2 & 25 \\
Colon & HCT-116 & 12 \\
Colon & Caco-2 & $>50$ \\
Epithelial (Normal) & fR-2 & $>>50$ \\
\hline
\end{tabular}

depicted that RLX showed high efficiency against HCT116 as reflected by its relative $\mathrm{IC}_{50}$ values and no cytotoxicity against fR-2 cells.

\section{Effect of RLX treatment on NFKB and caspase-3 protein expression in HCT-116 cell line}

We next examined the effect of RLX on NFKB and caspase-3 protein expression levels by western blotting. Following $\operatorname{RLX}(0,10,20$ and $30 \mu \mathrm{M})$ treatment for $48 \mathrm{~h}$, western blot analysis revealed that RLX decreased 1 to 0.1

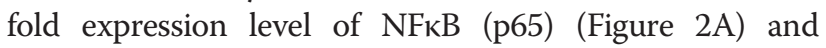

increased 1 to 2 fold caspase-3 expression level (Figure 2C). However, significant effect on expression of $\mathrm{NFKB}$ protein was observed at 20 and $30 \mu \mathrm{M}$ (Figure 2B) and caspase-3 at 10, 20 and $30 \mu \mathrm{M}$ (Figure 2D) RLX concentration as compared to untreated and BEZ-235(10nM) (Positive control) thereby suggesting $\mathrm{NF}_{\kappa} \mathrm{B}$ down-regulation and caspase-3 up-regulation by RLX action.

\section{Exposure of RLX inhibits cell migration of HCT-116 cell monolayers}

Cell migration experiment was performed to confirm the inhibitory effect of RLX in HCT-116 cells. As shown in Figure 3A, RLX treatment at 10, 20 and $30 \mu \mathrm{M}$ showed HCT-116 cell migration inhibition when compared to untreated $(0 \mu \mathrm{M})$ and BEZ-235 (10 nM). However, at increased concentrations of RLX (20 and $30 \mu \mathrm{M})$, HCT-116 cells showed significant cell migration inhibition in a concentration dependent manner as compared to untreated control (Figure 3B).

\section{RLX treatment culminate microvilli loss in HCT-116 cells}

As exhibited in Figure 4A, untreated cells were having intact microvilli all over the surface. However, RLX treatment at 10, 20 and $30 \mu \mathrm{M}$ resulted in blebbing of the plasma membrane and loss of microvilli. Interestingly,

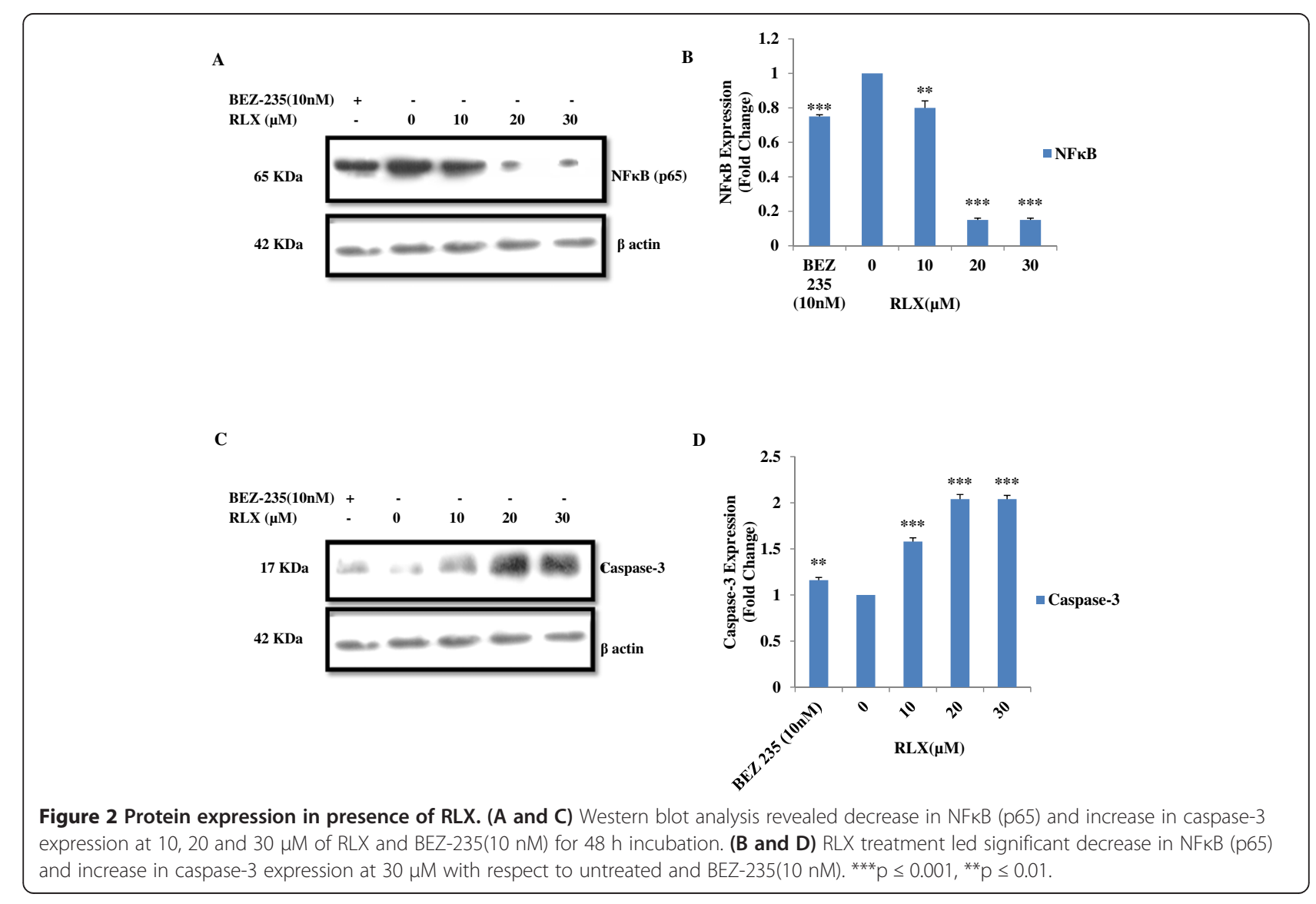



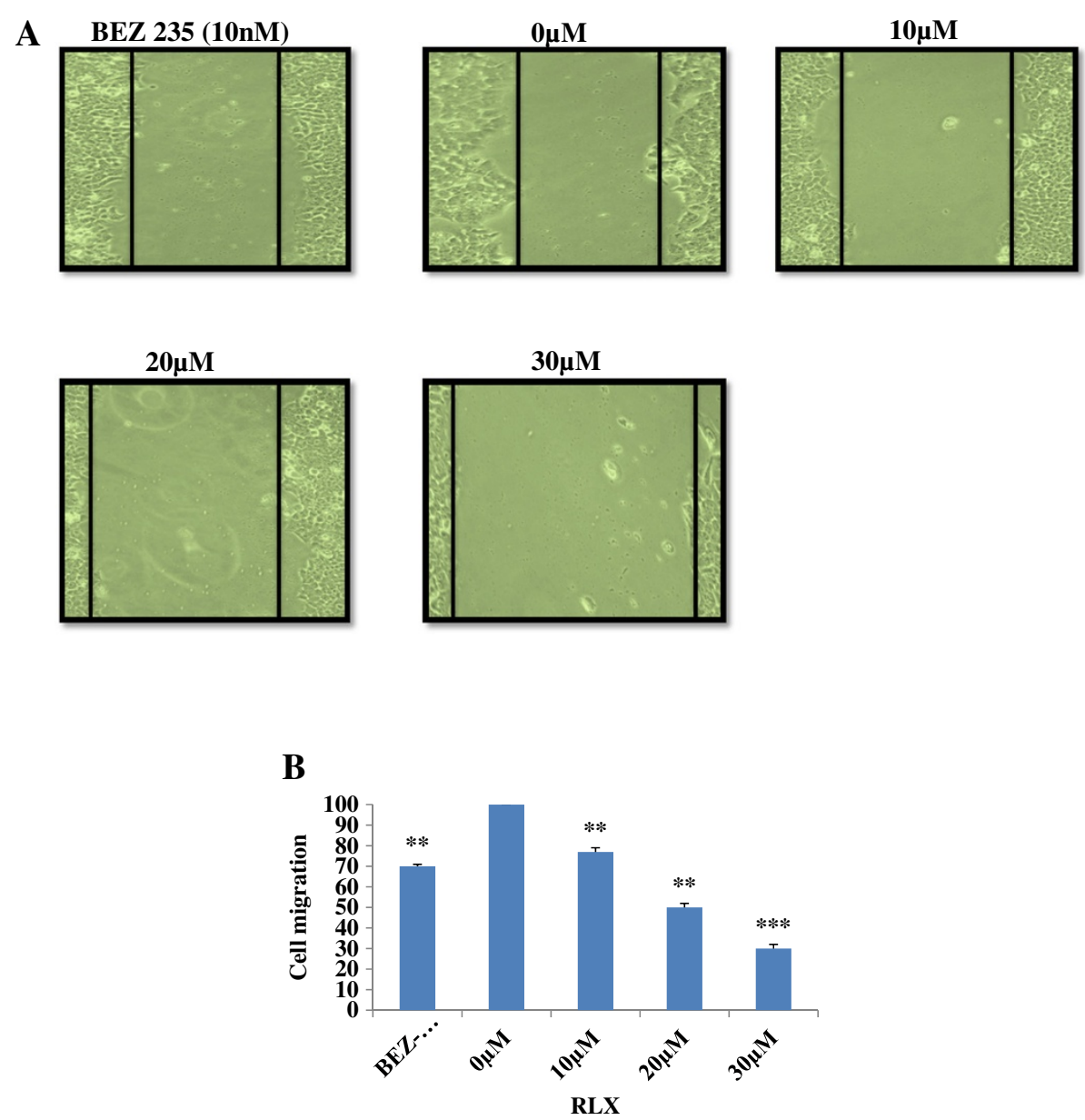

Figure 3 Cell migration in HCT-116. (A) Wound healing assay of HCT-116 stable cell lines. Cells were seeded in 6 well plate and after overnight incubation confluent monolayer cells were scraped with sterile $200 \mu \mathrm{l}$ pipette tip and allowed to migrate for $48 \mathrm{~h}$ in presence of different concentrations of RLX. The wounded areas were photographed at $48 \mathrm{~h}$. Wound areas were measured by Image J software. (B) RLX showed concentration dependent cell migration inhibition in HCT-116 monolayers. Significant inhibition on cell migration was found at $30 \mu \mathrm{M}$ concentration of RLX as compared to untreated and BEZ-235 control. Results are presented as mean \pm standard deviation. ${ }^{* *} \mathrm{p} \leq 0.001,{ }^{* *} \mathrm{p} \leq 0.01$.

most significant smoothening of the cell surface, shrinkage of size and blebbing of the plasma membrane and apoptotic body formation were observed at $30 \mu \mathrm{M}$ concentration of RLX when compared with untreated and BEZ-235. Overall, SEM data clearly demonstrated typical early apoptotic phenomena and loss of microvilli as compared to untreated control.

\section{Nuclear condensation in RLX treated HCT-116 cells}

We next examined the morphological insights caused by RLX in HCT-116 cells using diamidine phenyl indoledihrdrochloride (DAPI) staining. Uniformly spherical HCT-116 cell with normal morphology was observed in untreated cultures, whereas chromatin condensation and chromosomal DNA cleavage were observed when HCT116 cells were treated with RLX $(10,20,30 \mu \mathrm{M})$ and BEZ-235 (10 nM). As shown in Figure 4B, with increase in concentration $(10,20,30 \mu \mathrm{M})$ of RLX there is increase in nuclear condensation and formation of apoptotic vesicles. However, prominent effect was seen at a concentration of 20 and $30 \mu \mathrm{M}$ treated cultures. Overall these results suggested the ability of RLX to induce apoptotic morphology in HCT-116 cells.

\section{Discussions}

In current study, an interesting correlation was revealed for the first time between various regulatory and phenotypic events of RLX with apoptosis. We first evaluated the growth inhibitory and cytotoxic effect of vasicinone analogues including RLX against panel of human cancer cell lines in vitro which includes Leukemia (THP-1), Prostate (PC-3), Breast (MCF-7, T47D), Pancreatic (MIAPaca 2), Colon (HCT-116, Caco-2) and normal epithelial cells (fR-2). Notably, we found for the first time that RLX inhibited cell growth and more importantly showed concentration dependent inhibition against panel 
A

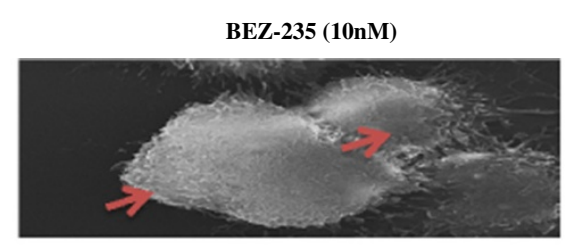

$10 \mu \mathrm{M}$

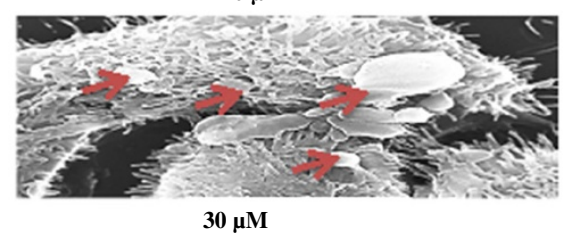

$30 \mu \mathrm{M}$

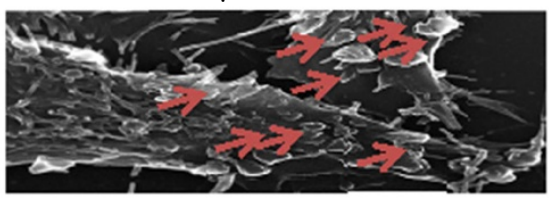

B

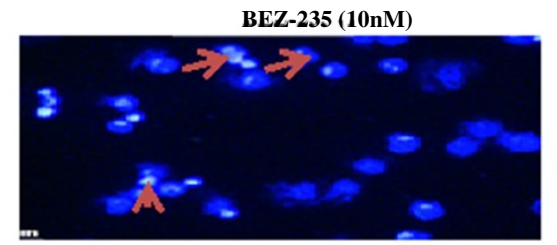

$10 \mu \mathrm{M}$

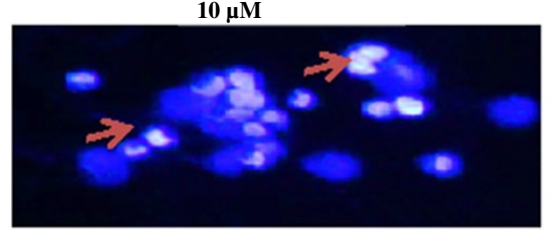

$30 \mu \mathrm{M}$

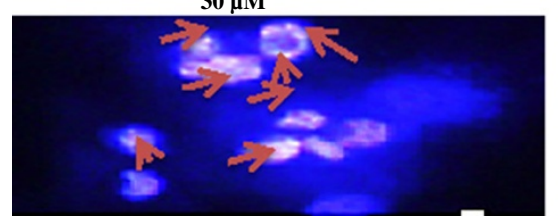

$\mathbf{0} \boldsymbol{\mu M}$

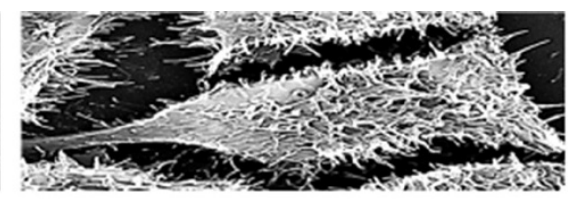

$20 \mu \mathrm{M}$
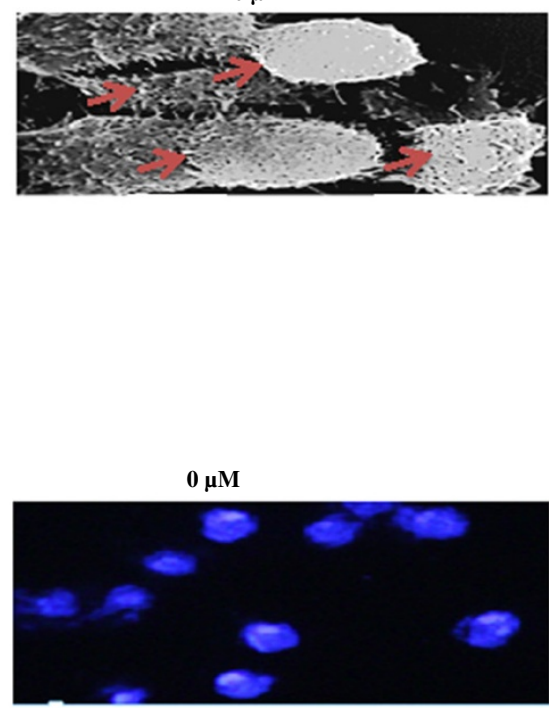

$20 \mu \mathrm{M}$

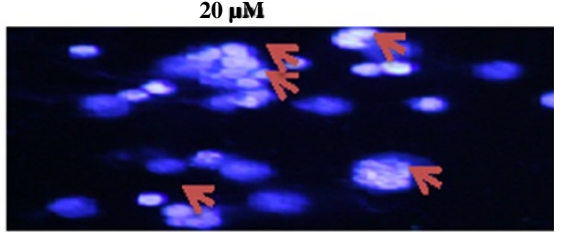

Figure 4 Microscopic studies in presence of RLX. (A) Scanning electron microscopy in HCT-116 cells. The untreated control cells (0 $\mu$ M) showed rough surface and microvilli. The treatment of RLX for $24 \mathrm{~h}$ caused reduction in cell size, smoothening of cell surface, blebbing of the plasma membrane and loss of microvilli. (B) Fluorescence microscopy in HCT-116 cells. HCT-116 cells were treated with different concentration of RLX for $48 \mathrm{~h}$ and stained with DAPI followed by analysis for nuclear condensation. Data are representative of one of the three

independent experiments.

of cancer cell lines tested. Besides, maximum and potent growth inhibition following RLX treatment was observed in human colon cancer cell line i.e. HCT-116. Keeping this in view, we further evaluated $\mathrm{IC}_{50}$ value of RLX against THP-1, PC-3, MCF, T47D, MIAPaca-2, HCT-116, Caco-2 and fR-2 cell lines by MTT assay, which was found minimum in HCT-116 cells. Overall, these results depicted that RLX showed significant effect against HCT-116 and least effect on Caco-2 colon cancer cell proliferation as reflected by relative $\mathrm{IC}_{50}$ value. Since the $\mathrm{NF}_{\kappa} \mathrm{B}$ pathway is important for cell survival, proliferation, cell cycle progression and migration which therefore affects regulation of proliferative, anti-apoptotic, pro-apoptotic and cell cycle regulatory molecules and thus results in cell survival, proliferation, progression and migration of numerous cancers [13]. NFkB promotes cell survival via the induction of proteins that inhibits the components of apoptotic machinery in normal as well as cancerous cells [14]. To evaluate the mechanism by which effect of RLX occurred, we further examined the effect on NFKB protein expression. The most abundant form of NFKB consists of a $\mathrm{p} 50$ subunit and a p65 subunit. In its inactive form, $N F K B$ is located in the cytoplasm however, upon activation by various stimuli, it translocates to the nucleus, where it may 
activate genes leading to cell survival or proliferation [15]. Notably, our study demonstrated that exposure to RLX resulted in remarkable down-regulation in expression of NFkB (p65). Furthermore, caspases play a pivotal role in the mechanism of apoptosis as they are both the initiators and executioners. Among caspases, caspase- 3 is a frequently activated death protease, which catalyzes the specific cleavage of many key cellular proteins resulting in apoptosis [16]. Importantly, caspase-3 is crucial for apoptotic chromatin condensation and DNA fragmentation in all cell types. Here, we show that RLX mediates caspase-3 up-regulation in HCT-116 cells. Taken together, these data indicated that $\mathrm{NFKB}_{\mathrm{B}}$ and caspase-3 play a pivotal role in mediating RLX induced apoptosis in HCT-116 cells. Cell migration plays a critical role in tumor cell invasion and metastasis [17]. Cell migration and invasion represents an important property for chemotherapeutic agent other than having potential to cause specific cancer cell death. Molecules involved in cancer cell migration could be potential target for anti-metastasis therapy. We summarize how colon cancer cell migrate using RLX which is tested by measuring the gap between control and treatment groups. Although RLX was found to actively inhibit colon cancer cell migration. Notably, apoptosis is morphologically characterized by chromatin condensation, inter-nucleosome fragments, cell shrinkage, membrane blebbing and formation of apoptotic bodies without disruption of plasma membrane [18]. In view of promising potential of RLX as an apoptotic agent, we further performed scanning electron microscopy (SEM) to assess early apoptotic morphological changes in HCT-116 cells. Data depicted a loss of microvilli on the surface of treated colon malignant cells and therefore revealed smoothening of cell surface which altogether validates formation of typical apoptotic feature on RLX treatment. This was supported by fluorescence microscopy using DAPI with subsequent features of cell shrinkage, membrane blebbing, chromatin condensation and nuclear fragmentation in contrast to the control cells, which retained their polygonal structure.

\section{Conclusions}

We report for the first time that RLX has target based anticancer activity. A very important property for a candidate anti-cancer drug is the ability to induce tumor cell apoptosis [19] and RLX exhibits this important characteristic feature. These findings should be useful for development of molecule(s) targeted against various cancer signaling pathways.

\section{Methods}

Chemicals and source of antibodies and kits

Growth medium (MEM/RPMI), fetal calf serum, trypsin, penicillin, streptomycin, DMSO, proteinase K, RIPA Buffer, bisacrylamide, SDS, MTT dye, acrylamide, ammonium persulfate (APS), N, N, N', N' tetramethylethylenediamine (TEMED), 2-mercaptoethanol, DAPI, Tris base. All the above mentioned chemicals were obtained from Sigma. Chemiluminescent western blotting kit (Millipore), Quanti Pro BCA assay kit, 96 and 6 well plate (Iwaki), triton X (Hi-Media), EDTA (Hi-Media), ELISA plate reader (Bio-Rad). NFkB (p65), caspase-3 antibodies were purchased from Millipore Pvt Ltd.

\section{Synthesis and structure of RLX}

Synthesis of RLX been reported previously [11]. Chemical structure of RLX is shown in Figure 1A.

\section{Cell lines, growth medium and treatment conditions}

Human cancer cell lines; Leukemia (THP-1), Prostate (PC-3), Colon (HCT-116, Caco-2), Breast (T47D, MCF-7) Pancreatic (MIAPaca 2) and Normal epithelial (fR-2) were procured from European Collection of cell culture (ECACC), UK. Cells were grown in Minimum Essential Medium (MEM) and Roswell Park Memorial Institute medium (RPMI) supplemented with 10\% FCS and 1\% penicillin. Penicillin was dissolved in PBS and sterilized by filtering through $0.2 \mu \mathrm{m}$ filter in laminar air flow hood. Cells were cultured in $\mathrm{CO}_{2}$ incubator (New Brunswick, Galaxy 170R, eppendroff) with an internal atmosphere of $95 \%$ air and $5 \% \mathrm{CO}_{2}$ gas and the cell lines were maintained at $37^{\circ} \mathrm{C}$. The media was stored at low temperature $\left(2-8^{\circ} \mathrm{C}\right)$ and the medium for cryopreservation contained $20 \%$ FCS and 10\% DMSO in growth medium.

\section{Cell viability assay}

The MTT assay was used to assess the effect of the molecules on cell viability. In each well of a 96-well plate, cells with different densities were grown in $100 \mu \mathrm{L}$ of medium. After $24 \mathrm{~h}$, RLX was added to achieve a final concentration of 50, 30, 20, 10, $5 \mu \mathrm{M}, \mathrm{BEZ}-235$ (10 nM) and 5-Flurouracil $(20 \mu \mathrm{M})$ (Positive controls) respectively. $4 \mathrm{~h}$ prior to the completion of $48 \mathrm{~h}$ treatment of RLX and BEZ-235, $20 \mu \mathrm{L}$ of $2.5 \mathrm{mg} / \mathrm{mL}$ of MTT solution in PBS was added to each well. After $48 \mathrm{~h}$, supernatant was removed and formazan crystals were dissolved in $150 \mu \mathrm{L}$ of DMSO. Absorbance was then measured at $570 \mathrm{~nm}$ using an absorbance plate reader (Bio-Rad Microplate Reader). Data was expressed as percentage of the viable cells in treated relative to untreated conditions. The experiments were repeated thrice and carried in triplicates [20].

\section{Preparation of whole cell lysates and western blot analysis}

HCT-116 $\left(2 \times 10^{6}\right.$ cells $/ \mathrm{ml} /$ well $)$ cells were treated with RLX at 0 (untreated), 10, 20, $30 \mu \mathrm{M}$ and BEZ-235 (10 nM) (Positive control) for $48 \mathrm{~h}$. After that cells were trypsinized and suspended in cold RIPA buffer $(150 \mathrm{mM} \mathrm{NaCl}, 1.0 \%$ IGEPAL CA-630, 0.5\% sodium deoxycholate, 0.1\% SDS, 
$50 \mathrm{mM}$ Tris, $\mathrm{PH}$ 8.0) for $30 \mathrm{~min}$ on ice. The lysates were vortexed and then centrifuged at $14,000 \mathrm{~g}$ for $15 \mathrm{~min}$. Supernatant thus obtained was whole cell lysate which was stored at $-20^{\circ} \mathrm{C}$ for future use. Protein content was measured using BSA (1 mg/ml) and samples with unknown concentrations were plotted in a linear range of 0.5 to $30 \mu \mathrm{g} / \mathrm{ml}$ of the protein concentration and absorbance measured at $562 \mathrm{~nm}$. The above protein lysates were subjected to discontinuous SDS-PAGE at $100 \mathrm{~V}$ and electro transferred to polyvinylidene difluoride (PVDF) membrane (Millipore) for $2 \mathrm{~h}$ at $120 \mathrm{~V}$ at $4^{\circ} \mathrm{C}$. The membrane was blocked with $3 \%$ skimmed milk in PBS for $1 \mathrm{~h}$. After blocking, the membrane was probed with specific primary antibody for overnight at $4^{\circ} \mathrm{C}$ followed by 3 times washing with TBST for 5 min each. A dilution of secondary antibody (mouse and rabbit) conjugate was added for $1 \mathrm{~h}$ of incubation and signals were detected using Millipore Chemiluminescent western blotting kit and analyzed using X-ray film [20].

\section{Cell migration Assay}

HCT-116 cell monolayer (90\% confluent) was allowed to become quiescent in medium with $0.1 \%$ dialyzed fetal bovine serum for $24 \mathrm{~h}$. Further, cells were scraped to make a straight line wound and treated with RLX and BEZ-235 (Positive control) for $48 \mathrm{~h}$. Photographs were taken through an inverted microscope $(\times 40$ magnification) at $48 \mathrm{~h}$ and lengths of wound were determined by Image J (version 1.46) software [21].

\section{Cell surface examination with scanned electron microscopy}

HCT-116 $\left(0.5 \times 10^{5}\right.$ cells $\left./ \mathrm{ml}\right)$ were treated with RLX at 0 (untreated), 10, 20, $30 \mu \mathrm{M}$ and BEZ-235(10nM) (Positive control) concentration for $24 \mathrm{~h}$. Following PBS wash, fixation of cells was done with $2.5 \%$ glutaraldehyde in $0.1 \mathrm{M}$ cacodylate buffer for $1 \mathrm{~h}$ at $4^{\circ} \mathrm{C}$ and post fixed with $1 \% \mathrm{OsO}_{4}$ in the same buffer for $1 \mathrm{~h}$ at room temperature. Dehydration was done with ascending grades of acetone following critical point drying using liquid $\mathrm{CO}_{2}$. Gold coating (thickness $20 \mathrm{~nm}$ ) was done using sputter coater and viewed under electron microscope (JEOL JEM -100CXII) with ASID at 40KV [20].

Apoptotic characterization using fluorescence microscopy HCT-116 $\left(5 \times 10^{5}\right.$ cells $/ \mathrm{ml} /$ well $)$ cells were treated with RLX 0 (untreated), 10, 20, $30 \mu \mathrm{M}$ and BEZ-235 (10 nM) (Positive control) concentrations. After $48 \mathrm{~h}$ of incubation, cells were centrifuged at $3000 \mathrm{rpm}$ for $5 \mathrm{~min}$. Resuspended pellet was dissolved in PBS. The air dried smears were fixed in methanol at $-20^{\circ} \mathrm{C}$, stained with DAPI $(1 \mu \mathrm{g} / \mathrm{ml})$ and kept at $37^{\circ} \mathrm{C}$ for 20 minutes. Following PBS wash, mounting was done with glycerol: PBS (90:10) on coverslip and prepared slides were observed under fluorescence microscope (Olympus) using UV filter at $40 \times$ magnification [20].

\section{Statistical evaluation}

The results of three independent experiments were expressed as the mean \pm SD. Statistical evaluation was performed using an un-paired t-test. ${ }^{* * *} \mathrm{p} \leq 0.001,{ }^{* *} \mathrm{p} \leq 0.01$, ${ }^{*} \mathrm{p} \leq 0.05$.

\section{Competing interests}

The authors declare that they have no competing interests.

\section{Authors' contributions}

AKQ carried out cellular studies. AH helped to draft the manuscript. MAA performed chemisty studies. SA helped in data analysis and interpretation. SCT participated in data analysis and interpretation of chemisty part. PRS carried out microscopic studies. AKS performed manuscript review. DMM helped in data analysis and interpretation. AH participated in its design and interpretation. All authors read and approved the final manuscript.

\section{Acknowledgements}

Asif Khurshid Qazi would like to thank Council of Scientific and Industrial Research (CSIR), India for providing the Senior Research Fellowship (SRF). The authors would also like to acknowledge the Director, CSIR-IIIM, Jammu for providing research facilities. This article was communicated under Institutional Publication No. IIIM/1680A/2014.

\section{Author details}

${ }^{1}$ Cancer Pharmacology Division, CSIR-Indian Institute of Integrative Medicine, Jammu 180001, India. ${ }^{2}$ Bio-Organic Chemistry Division, CSIR-Indian Institute of Integrative Medicine, Jammu 180001, India. ${ }^{3}$ Department of Biochemistry, Jamia Hamdard (Hamdard University), New Delhi 110062, India.

Received: 6 December 2013 Accepted: 22 September 2014 Published: 10 October 2014

\section{References}

1. Jemal A, Bray F, Center MM, Ferlay J, Ward E, Forman D: Global cancer statistics. CA Cancer J Clin 2011, 61(2):69-90

2. Rupnarain C, Dlamini Z, Naicker S, Bhoola K: Colon cancer: genomics and apoptotic events. Biol Chem 2004, 385(6):449-464.

3. Hurwitz $\mathrm{H}$ : Integrating the anti-VEGF-A humanized monoclonal antibody bevacizumab with chemotherapy in advanced colorectal cancer. Clin Colorectal Cancer 2004, 4(Suppl 2):S62-S68.

4. Mano MS, Duhoux F: Colon cancer: update on adjuvant therapy. Clin Colorectal Cancer 2008, 7(3):178-183.

5. Naugler WE, Karin M: NF-kappaB and cancer-identifying targets and mechanisms. Curr Opin Genet Dev 2008, 18(1):19-26.

6. Aggarwal BB: Nuclear factor-kappaB: the enemy within. Cancer Cell 2004, 6(3):203-208.

7. Dormoy V, Danilin S, Lindner V, Thomas L, Rothhut S, Coquard C, Helwig JJ, Jacqmin D, Lang H, Massfelder T: The sonic hedgehog signaling pathway is reactivated in human renal cell carcinoma and plays orchestral role in tumor growth. Mol Cancer 2009, 8:123.

8. Kang KH, Lee KH, Kim MY, Choi KH: Caspase-3-mediated cleavage of the NF-kappa B subunit p65 at the $\mathrm{NH} 2$ terminus potentiates naphthoquinone analog-induced apoptosis. J Biol Chem 2001, 276(27):24638-24644.

9. Kim MK, Kang YJ, Kim DH, Hossain MA, Jang JY, Lee SH, Yoon JH, Chun P, Moon HR, Kim HS, Chung HY, Kim ND: A novel hydroxamic acid derivative, MHY218, induces apoptosis and cell cycle arrest through downregulation of NF-kappaB in HCT116 human colon cancer cells. Int J Oncol 2014, 44(1):256-264.

10. Roper J, Richardson MP, Wang WV, Richard LG, Chen W, Coffee EM, Sinnamon MJ, Lee L, Chen PC, Bronson RT, Martin ES, Hung KE: The dual $\mathrm{PI} 3 \mathrm{~K} / \mathrm{mTOR}$ inhibitor NVP-BEZ235 induces tumor regression in a genetically engineered mouse model of PIK3CA wild-type colorectal cancer. PLoS One 2011, 6(9):e25132. 
11. Zabeer A, Bhagat A, Gupta OP, Singh GD, Youssouf MS, Dhar KL, Suri OP, Suri KA, Satti NK, Gupta BD, Qazi GN: Synthesis and bronchodilator activity of new quinazolin derivative. Eur J Med Chem 2006, 41(3):429-434.

12. Sharma ML, Khajuria A, Kaul A, Chand D: Immunopharmacological properties of azepino [2, 1-b] quinazolin-12(6H)-one-7, 8, 9, 10-tetrahydro (RLX). Int J Immunopharmacol 1992, 14(6):979-986.

13. Schmid JA, Birbach A, Hofer-Warbinek R, Pengg M, Burner U, Furtmuller PG, Binder BR, de Martin R: Dynamics of NF kappa B and Ikappa Balpha studied with green fluorescent protein (GFP) fusion proteins. Investigation of GFP-p65 binding to DNa by fluorescence resonance energy transfer. J Biol Chem 2000, 275(22):17035-17042.

14. Shen HM, Tergaonkar V: NFkappaB signaling in carcinogenesis and as a potential molecular target for cancer therapy. Apoptosis 2009, 14(4):348-363.

15. Swinney DC, Xu YZ, Scarafia LE, Lee I, Mak AY, Gan QF, Ramesha CS, Mulkins MA, Dunn J, So OY, Biegel T, Dinh M, Volkel P, Barnett J, Dalrymple SA, Lee S, Huber M: A small molecule ubiquitination inhibitor blocks NF-kappa B-dependent cytokine expression in cells and rats. J Biol Chem 2002, 277(26):23573-23581.

16. Porter $\mathrm{AG}$, Janicke RU: Emerging roles of caspase-3 in apoptosis. Cell Death Differ 1999, 6(2):99-104.

17. Yamaguchi $\mathrm{H}$, Wyckoff J, Condeelis J: Cell migration in tumors. Curr Opin Cell Biol 2005, 17(5):559-564.

18. Wyllie AH, Morris RG, Smith AL, Dunlop D: Chromatin cleavage in apoptosis: association with condensed chromatin morphology and dependence on macromolecular synthesis. J Pathol 1984, 142(1):67-77.

19. Owa T, Yoshino H, Yoshimatsu K, Nagasu T: Cell cycle regulation in the G1 phase: a promising target for the development of new chemotherapeutic anticancer agents. Curr Med Chem 2001, 8(12):1487-1503.

20. Qurishi Y, Hamid A, Sharma PR, Wani ZA, Mondhe DM, Singh SK, Zargar MA, Andotra SS, Shah BA, Taneja SC, Saxena AK: PARP cleavage and perturbance in mitochondrial membrane potential by 3-alphapropionyloxy-beta-boswellic acid results in cancer cell death and tumor regression in murine models. Future Oncol 2012, 8(7):867-881.

21. Lee DE, Chung MY, Lim TG, Huh WB, Lee HJ, Lee KW: Quercetin suppresses intracellular ROS formation, MMP activation, and cell motility in human fibrosarcoma cells. J Food Sci 2013, 78(9):H1464-H1469.

doi:10.1186/1471-2121-15-36

Cite this article as: Qazi et al:: Cell specific apoptosis by RLX is mediated by NFKB in human colon carcinoma HCT-116 cells. BMC Cell Biology 2014 15:36.

\section{Submit your next manuscript to BioMed Central and take full advantage of:}

- Convenient online submission

- Thorough peer review

- No space constraints or color figure charges

- Immediate publication on acceptance

- Inclusion in PubMed, CAS, Scopus and Google Scholar

- Research which is freely available for redistribution 